\title{
Accessing research literature: A mixed-method study of academics in Higher Education Institutions in Nepal
}

\author{
Simkhada P1-6, van Teijlingen E-7, Devkota B ${ }^{8-9}$, Pathak SR ${ }^{10-11}$, Sathian $B^{12}$
}

${ }^{1}$ Senior Lecturer in International Health, School of Health and Related Research (ScHARR), University of Sheffield, Sheffield, UK

${ }^{2}$ Honorary Lecturer, University of Aberdeen, UK

${ }^{3}$ Visiting Fellow, Bournemouth University, UK.

${ }^{4}$ Adjunct Faculty- Datta Meghe Institute of Medical Sciences (Deemed University) Nagpur, India

${ }^{5}$ Visiting Professor, Manmohan Institute of Health Science, Tribhuvan University, Nepal.

${ }^{6}$ Visiting Professor, Nobel College, Pokhara University, Kathmandu, Nepal.

7 Professor, School of Health \& Social Care, Bournemouth University, Bournemouth, UK.

${ }^{8}$ Reader-Faculty of Education, Tribhuvan University Kathmandu, Nepal

${ }^{9}$ Chairperson- Development Resource Centre, Kathmandu, Nepal

10 Professor \& Head of Central Department of Population Studies, Tribhuvan University, Kathmandu, Nepal

11 President, Population Association of Nepal (PAN), Kathmandu, Nepal.

${ }^{12}$ Assistant Professor, Manipal College of Medical Sciences, Pokhara, Nepal.

\section{Chief Editor}

H S Supram

Technical Editor

Dr. Nishida Chandrasekharan

Formatting Editor

Dr. Abhilash E S
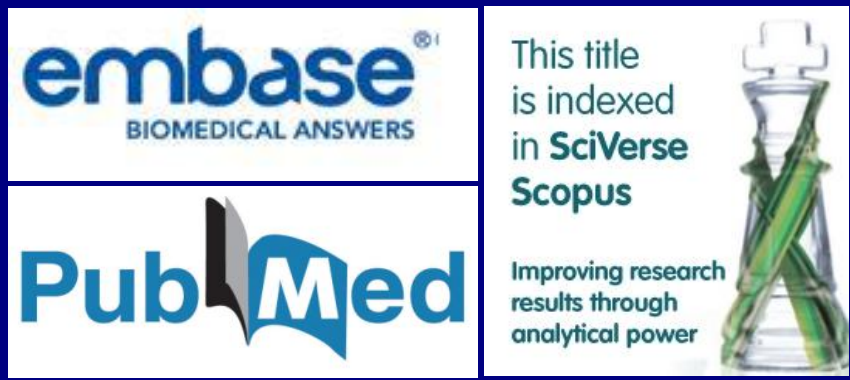

Original Article

Corresponding Author

Dr. Padam Simkhada, PhD

Senior Lecturer in International Health,

School of Health and Related Research (ScHARR),

University of Sheffield, Sheffield, UK

E-mail: p.simkhada@sheffield.ac.uk

\section{Abstract}

\section{Background:}

Research in Higher Education (HE), particularly in health and medical sciences plays a crucial role, not only in enhancing knowledge and skills of students and academics, but also in helping to develop managers and policy makers who rely on evidence-based planning and programming. This paper reports university teacher's knowledge and practices in 


\section{Accessing research literature}

accessing to electronic research-based evidences in health and medical sciences in Nepal.

Material and Methods:

This was mixed-methods study comprising a selfadministered questionnaire completed by HE teachers and informant key interviews with authorities of $\mathrm{HE}$ institutions. A total of 15 out of the total 40 institutions offering $\mathrm{HE}$ above Bachelors level on health-related subjects were included for the study.

Results:

The response rate was 68\%; 244 out of $360 \mathrm{HE}$ teachers completed self-administered questionnaire. The respondents comprised nurses (36\%), followed by doctors $(23 \%)$, public health practitioners $(18 \%)$, dentists $(17 \%)$ and pharmacists (12\%). Most of the HE teachers reported that they have computer skills and possess their own computer. Two-thirds (66\%) of the HE teachers had work email and almost all (93\%) have a personal email ID. All institutions had a computer lab and/or library. Almost all teachers had internet access at work but the internet was reportedly slow. Each institution had a librarian to support to the students and staff but only a third of teachers sought their help. Many do not know what kind of support librarians can provide. Less than half of the staff had accessed electronic research materials. This proportion varied between HE institutions ranging from 13 to $83 \%$. HINARI and PubMed were the mostly used research databases. Less than half of respondents (48\%) had published research papers in peerreviewed journals, and only $19 \%$ published a paper based on a systematic review. Female $\mathrm{HE}$ teachers were less likely to publish (32\%) than males (68\%). More readers and professors had published (75\%) than instructors/assistant lecturers (30\%) and lecturers (45\%).

\section{Conclusions:}

Accessing electronic research literature provides an opportunity to gathering up-to-date research-based information that should be core to all health curricula. We call upon curriculum developers and university authorities in Nepal to revise health curricula and help build electronic searching skills among staff and students.

Keywords: Electronic research literature; Research Article; Higher Education; Nepal

\section{Introduction}

Nepal has made strides of progress in health sciences and medical education over the past decade. Over 18 medical colleges have already been established and a few are on the pipeline. There are more than 70 nursing colleges (both in private and public sectors) and equal number of other health science colleges and courses, e.g. public health, pharmacy, physiotherapy and radiography ${ }^{1}$.

The overall health research environment is still relatively poor in $\mathrm{Nepal}^{2}$. Nepali researchers have limited publications in peer reviewed journals compared to their non-Nepali counterparts. The number of publications seems lower in the public university compared to the private universities ${ }^{3}$.
The use of available evidence-based information is necessary before we can address health problems in Nepal, however Higher Education (HE) institutions lack knowledge as well as resources for utilising research published even in free and low priced journals ${ }^{4}$. Moreover, many of the curricula of HE institutions do not seem strong on research methodology training ${ }^{5}$. Simkhada and colleagues (2013) argued that health profession curricula should include clearer instructions to students on how to access the mostup-to-date research literature and how to appraise research articles 5 .

Access to research information is an essential element in strengthening health sciences and medical practices, and empowering local experts to find solutions to health problems and to encourage the evidence based practice. Evidence-based practice is important to deliver the quality of care. However lack of research literature tends to be a serious obstacle for health professionals and researchers in the developing world. According to a World Health Organization survey, of the 75 countries with an annual income per capita of less than US $\$ 1000,56 \%$ of medical institutions have had no subscriptions to journals over the last five years ${ }^{6}$. Despite the enormous disease burden in Nepal, research is often viewed as expenditure rather than an investment. Moreover, case studies from Nepal, Bangladesh, and Pakistan report that most government funding for research goes towards training, salaries, and infrastructure, resulting in research projects being largely funded (and influenced) by external donors ${ }^{7}$. Due to high subscription fees and complicated licensed agreements, many medical schools and HE institutions in Nepal are unable to subscribe the health-science related journals. Therefore, many researchers, HE teachers and students often have little access to the published research literature ${ }^{2}$. The advent of electronic publishing over the Internet generally improved global distribution of research information. Scientists, researchers, academics, policymakers and medical practitioners in developing country institutions now can have access to advanced and up-todate peer-reviewed research literature. Thousands of international scientific journals can be accessed online. Moreover, specialist databases, indexes, and reference books also available in several languages. Full-text articles can be downloaded for saving, printing or reading on screen. Many articles are available online before they are published in print. Accessing the available research information is very essential for institutions to bridge the research information gap. Therefore, there is need to improve the access to research information for Nepalese academics and researchers. This study aimed to assess $\mathrm{HE}$ teachers' knowledge, skills and competence on accessing electronic research literature on health sciences in Nepal.

\section{Materials and Methods Study design and the participants:}

A descriptive research design with a mixed-methods approach was used for the study during the period first half of 2009 to first half of 2010. The research comprised a questionnaire survey of HE staff and interviews with key 
informants in the HE sector. In view of higher concentration of the medical institutions around the capital Kathmandu, this study covered all the medical, nursing and public health institutions providing higher education above Bachelor's level within the Kathmandu Valley. Furthermore, it included the three major institutions located in different parts outside Kathmandu: BPKIHS (BP Koirala Institute of Health Sciences), the only institution outside Kathmandu Valley with a Masters in Public Health at the time of study; Manipal College in Pokhara; and Kathmandu University School of Medical Science (KUMS) in Dhilukhel. Out of the total $1088 \mathrm{HE}$ teachers on the HE institutions' records, 360 were physically available during the study visits and were willing to participate in the self-administered questionnaire. Of the $360 \mathrm{HE}$ teachers who were given the questionnaire, $244(68 \%)$ returned a completed questionnaire.

\section{Questionnaire design}

An extensive review of the literature, combined with exploratory research ${ }^{5}$ and qualitative piloting ${ }^{8}$ contributed to the development and refinement of a structured questionnaire in English.

\section{Sample size calculation}

The sample size calculation suggested that for a $95 \%$ confidence interval and significance level $\alpha=5 \%, P=0.5, Q$ $=0.5$, allowable error $=14 \%$, whereby $\mathrm{P}=$ Proportion of $\mathrm{HE}$ teachers had access to electronic research databases among the 50 respondents of the pilot study sample from Nepal, the required sample size was $205^{9}$.

\section{Qualitative Research design}

Interviews were conducted face-to-face with principals or campus chiefs, head of the departments and subject committee members. In total twelve key informant interviews were conducted. The qualitative interviews were analyzed thematically by reading transcriptions repeatedly to generate key themes ${ }^{10}$.

\section{Outcome variable}

The main outcome variable was the HE teachers access to electronic research databases.

\section{Explanatory variables}

Factors which are taken into account at individual level were: gender, institution, designation and discipline.

\section{Data management and statistical analysis}

The data collected were analyzed using Excel 2003, Statistical Package for the Social Sciences (SPSS) for Windows Version 16.0 (SPSS Inc; Chicago, IL, USA) and EPI Info 3.5.1 Windows Version. The chi square test was used to observe the relationship between the variables, and $p<$ 0.05 was considered as statistically significant.

\section{Ethical committee approval}

The study received ethical approval from the Nepal Health Research Council (NHRC) and individual consent was taken by all participants.

\section{Results:}

Out of the total 244 higher education (HE) teachers, fewer men completed the questionnaire $(n=108$ or $44.3 \%)$ than women ( $n=136$ or $55.7 \%)$. By discipline or educational programme, the majority was from nursing (36.1\%) followed by public health (17.6\%) and pharmacy (11.9\%).

\section{Accessing research literature}

The majority of staff was lecturer (47.5\%) and nearly threequarters $(72 \%)$ had completed Masters degree, the single largest proportion of the sample was aged 30 to 39 years (43.4\%), whilst $28.8 \%$ was younger (20-29 years). Overall, $42 \%$ of $\mathrm{HE}$ teachers had been educated abroad. The proportion seems higher at BPKIHS (66\%) followed by $55 \%$ at TU (Tribhuvan University) and $52 \%$ at PoU (Pokhara University). The proportion of females educated abroad (42\%) was lower than that of males (55\%).

Two-thirds of staff had a work email account, the lower raking staff less $(60.6 \%)$ than readers/professors $(77.2 \%)$, but there was no statistically significant difference between HEls. There was a significant gender difference, with $75.9 \%$ of men having work email and only $58.8 \%$ of female staff $(\chi 2=7.891 ; p=0.006)$. The availability of computers for academic use seemed good at all level of HE teachers, at different universities and for both sexes. Availability was little higher at BPKIHS and PoU, but this was not statistically significant $(p=0.067)$. Internet was available in all HEls. When it comes to the question of access of personal computer and internet access, it was reported only in BPKIHS where every faculty member had a personal laptop and $7 / 24$ access to internet, including the online journals. The qualitative findings reiterated this, for example:

" Here every faculty has a personal computer and space with regular internet facility, 24 hours a day, seven days a week. They can access online journals anytime they like".

-Key informant, BPKIHS

Most students (89\%) had access to internet. Almost all students from BPKIHS and 96\% from KU (Kathmandu University) had access to the internet, but a lower proportion at Pokhara University. One key informant reported that students often visit other organisations to access the literature:

".. (students) are far better than us (teachers) using internet and are very curious to learn. They also visit different organisations (NHRC, Family Health Division Teku, Primary Health Care Center, Bagbazar) to get other grey literatures. We usually ask them to visit these organisations because they have systematic management of reading materials and updated literature in their library.

\section{-Interviewee 1}

However, some staff thought students did not want to make the effort to learn about accessing electronic journals:

"Students ... always seek for easy way that makes them lazy." -Interviewee 2

Staff from all colleges reported in interviews that they had had IT facilities, but they recognised the following problems: (a) not all computers were equally good; (b) not having enough computers for all students; or (c) no generator when there was load-shedding. The following quote illustrates several issues:

"You can see the computer with internet at our tables. However, it is too slow and boring to wait for downloading, no free access of websites. I have heard that the staff in lab is highly qualified in computer". - Interviewee 5 


\section{Access to Electronic Research Database}

Table 1 shows that less than half of HE teachers (49\%) had access to electronic research databases. A small proportion (14\%) even didn't know whether it was available at their $\mathrm{HEI}$. The self-reported access was highest in BPKIHS and lowest at TU and PU (Purbanchal University).

Table 1: Access to electronic research database at the HEls

\begin{tabular}{|c|c|c|c|c|c|c|c|}
\hline Response & TU & PU & KU & PoU & BPKIHS & Total & value \\
\hline Yes & $33(58.9)$ & $\begin{array}{c}25 \\
(33.3)\end{array}$ & $\begin{array}{c}39 \\
(58.2)\end{array}$ & $\begin{array}{c}3 \\
(13.0)\end{array}$ & $\begin{array}{c}19 \\
(82.6)\end{array}$ & $\begin{array}{c}119 \\
(48.8)\end{array}$ & \\
\hline No & $\begin{array}{c}15 \\
(26.8)\end{array}$ & $\begin{array}{c}44 \\
(58.7)\end{array}$ & $\begin{array}{c}17 \\
(25.4)\end{array}$ & $\begin{array}{c}13 \\
(56.5)\end{array}$ & $3(13.0)$ & $\begin{array}{c}92 \\
(37.7)\end{array}$ & $\chi^{2}=45.002$ \\
\hline $\begin{array}{l}\text { Do not } \\
\text { know }\end{array}$ & $8(14.3)$ & $\begin{array}{c}6 \\
(8.0)\end{array}$ & $11(16.4)$ & $\begin{array}{c}7 \\
(30.4)\end{array}$ & $1(4.3)$ & $\begin{array}{c}33 \\
(13.5)\end{array}$ & $P=0.001$ \\
\hline otal & 56 & 75 & 67 & 23 & 23 & $\begin{array}{c}244 \\
(100.0)\end{array}$ & \\
\hline
\end{tabular}

The data disaggregated by academic programme shows access to research database was highest in dentistry (Fig. 1).

Figure 1: Teacher access to electronic database by discipline

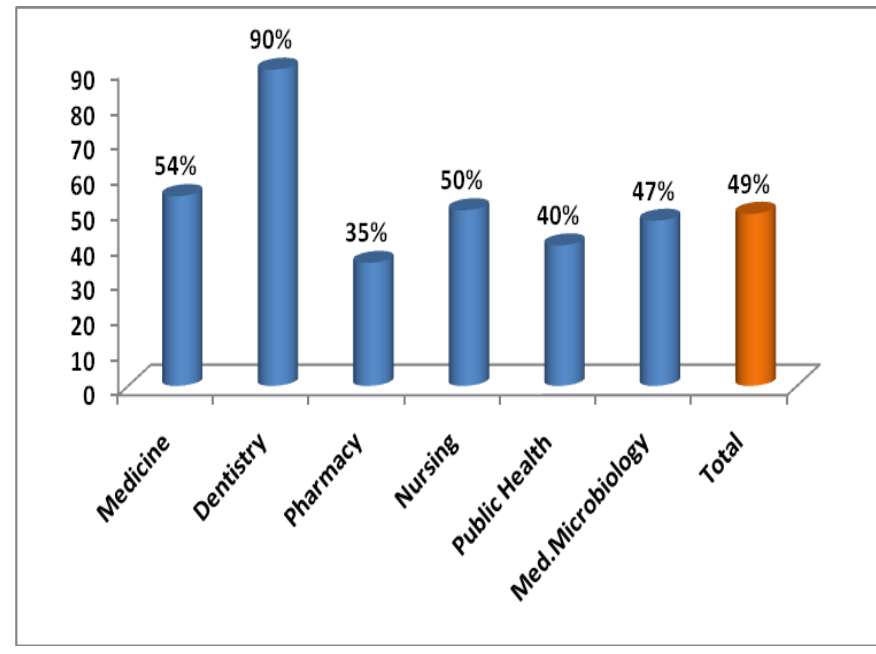

Fewer than half of HE teachers from other programmes had access to it $(P=0.001)$.

The key informants however expressed that younger staff were more familiar with IT in general, e.g.:

"I'm sure teachers are not up to date on this matter ... the teachers who are young are somehow okay, they have at least email ID." -Key Informant, $K U$

Of the total $119 \mathrm{HE}$ teachers who reported their HEls had subscribed electronic research database, more than one third (43\%) had access to HINARI followed by a combination of PubMed and HINARI (16\%) and PubMed (3.4\%). In interviews $\mathrm{HE}$ teachers, particularly from BPKIHS mentioned Blackwell Synergy, HINARI, PubMed and Cochrane ( 6 out of 7 respondents). Key informants had mixed responses regarding subscription of online databases.

in HEls. The responses seem similar in all universities. By discipline more than half of the HE teachers teaching pharmacy (52\%) and public health (51\%) reported that they
"No online journal or data base are subscribed. We actually don't know that, basically we search information in Google." -Interviewee 5

\section{Teaching Research and Accessing Literature}

Overall, only $49 \% \mathrm{HE}$ teachers had taught research-related subjects. The proportion was consistent across all universities, except BPKIHS (100\% say they teach research) whilst $\mathrm{HE}$ teachers from public health (74\%) and medical microbiology (65\%) were more likely to have taught research methods.

The majority (84\%) of the HE teachers had taught research for less than five years. Of the total HE teachers who taught research, $82 \%$ had taught how to access research literature. While the proportion of teachers who taught accessing research literature of all $\mathrm{HE}$ teachers $(\mathrm{N}=244)$ only $40 \%$ taught accessing electronic research databases.

Table 2: Methods used while teaching accessing research literature*

\begin{tabular}{|c|c|c|c|}
\hline 1. By university & $\begin{array}{l}\text { Manual } \\
\text { search }\end{array}$ & $\begin{array}{l}\text { Online other than } \\
\text { electronic database } \\
\text { search }\end{array}$ & $\begin{array}{c}\text { Online } \\
\text { electronic } \\
\text { database search }\end{array}$ \\
\hline TU (N=19) & $13(68.4)$ & $13(68.4)$ & $9(47.4)$ \\
\hline$P U(N=24)$ & $20(83.3)$ & $10(41.7)$ & $5(20.8)$ \\
\hline $\mathrm{KU}(\mathrm{N}=27)$ & $13(48.1)$ & 14 (51.9) & $12(44.4)$ \\
\hline PoU (N=7) & $2(28.6)$ & $5(71.4)$ & 3 (42.9) \\
\hline BPKIHS (N=21) & 12 (57.1) & $20(95.2)$ & 12 (57.1) \\
\hline Total row \% & $60(61.2)$ & $62(63.3)$ & $41(41.8)$ \\
\hline \multicolumn{4}{|l|}{ 2. By discipline } \\
\hline $\begin{array}{c}\text { Medicine } \\
(\mathrm{N}=26)\end{array}$ & $10(38.5)$ & $15(57.7)$ & $12(46.2)$ \\
\hline Pharmacy $(\mathrm{N}=6)$ & $4(66.7)$ & $4(66.7)$ & $3(50.0)$ \\
\hline Nursing $(\mathrm{N}=31)$ & $24(77.4)$ & $19(61.3)$ & $12(38.7)$ \\
\hline $\begin{array}{l}\text { Public Health } \\
\qquad(\mathrm{N}=23)\end{array}$ & $15(65.2)$ & $15(65.2)$ & $9(39.1)$ \\
\hline $\begin{array}{c}\text { Med. } \\
\text { Microbiology } \\
(\mathrm{N}=10)\end{array}$ & $5(50.0)$ & $7(70.0)$ & $4(40.0)$ \\
\hline Dentistry $(\mathrm{N}=2)$ & $2(100.0)$ & $2(100.0)$ & $1(50.0)$ \\
\hline $\begin{array}{c}\text { Total row \% } \\
\quad(N=98)\end{array}$ & $60(61.2)$ & $62(63.3)$ & $41(41.8)$ \\
\hline
\end{tabular}

* Multiple answers are possible for each respondent, hence total $>100 \%$.

Table 2 shows the distribution of various method of accessing research currently being taught. HE teachers indicated that they used online materials other than electronic database (e.g. Google) (63\%) followed by manual search (61\%). In total, only $42 \%$ of the HE teachers used searching of online electronic research databases. Table 2 also shows a difference between academic disciplines.

Interestingly, only $44 \% \mathrm{HE}$ teachers were themselves trained on accessing electronic database during their study were taught accessing research literature while they were student but medical biology and nursing reported it the least (35\% and $39 \%$ respectively). 
The reasons behind why they were not taught accessing online research materials included, 'It was not incorporated into the curricula'(88 \%), 'Due to lack of computer'(10\%) , 'internet facility' (5\%), and 'Due to lack of trained teacher' (9\%). Key informant interviews from across universities revealed that their academic curricula have certain topics on general research methodology, sampling, field survey and literature review but specific topics on accessing electronic research literature and systematic reviews were lacking.

"Our curricula cover importance of research in medical/public health, research design, methodology, literature review, data analysis and use of research findings. The faculty members/students (of $\mathrm{MPH}$ ) have to devote about $25 \%$ of their time in delivering/engaging in research activities. MPH students are fully engaged a six month long research for their thesis However, we have very brief teaching on accessing online research and systematic reviews." -Key Informant, BPKIHS

\section{Research Publications by the HE Teachers}

Table 3: HE teachers who have published research papers in peer reviewed journals

\begin{tabular}{|c|c|c|c|}
\hline 1. By University & No. & Percentage & $x^{2}$ value \\
\hline TU & 32 & 57.1 & \\
\hline PU & 25 & 33.3 & \\
\hline KU & 36 & 53.7 & $P=0.023$ \\
\hline PoU & 6 & 26.1 & \\
\hline BPKIHS & 17 & 73.9 & \\
\hline Total & 116 & 47.5 & \\
\hline \multicolumn{4}{|l|}{ 2. By Discipline } \\
\hline Medicine & 35 & 61.4 & \\
\hline Pharmacy & 9 & 31.0 & \\
\hline Nursing & 25 & 28.4 & $P=0.001$ \\
\hline Public Health & 26 & 60.5 & \\
\hline $\begin{array}{c}\text { Medical } \\
\text { Microbiology }\end{array}$ & 13 & 76.5 & \\
\hline Dentistry & 8 & 80.0 & \\
\hline Total & 116 & 47.5 & \\
\hline \multicolumn{4}{|l|}{ 3. By gender } \\
\hline Male & 73 & 67.6 & \\
\hline Female & 43 & 31.6 & $P=<0.001$ \\
\hline Total & 116 & 47.5 & \\
\hline \multicolumn{4}{|l|}{ 4. By designation } \\
\hline $\begin{array}{c}\text { Instructor/Asst. } \\
\text { Lecturer }\end{array}$ & 21 & 29.6 & \\
\hline Lecturer & 52 & 44.8 & $P=0.001$ \\
\hline Reader/Professor & 43 & 75.4 & \\
\hline Total & 116 & 47.5 & \\
\hline
\end{tabular}

Less than half of the HE teachers (48\%) have published research papers in peer-reviewed journals (Table 3 ). The proportion of HE teachers from BPKIHS seems higher (74\%) and least in PoU (26\%). The trend is similar in TU (57\%) and KU (54\%). Table 3 also shows that by discipline the difference in publishing research papers between dentistry teachers and medical microbiology teachers, on the one hand, and pharmacy and nursing teachers, on the other, is statistically significant $(p=0.001)$. At the same time the gender difference is also significant as less than a third of the females (32\%) have published research papers against $68 \%$ of their male counterparts, while by designation, readers and professors are most likely to have produced research publications (75\%).

Table 4: HE teachers who have published journal articles based on systematic review

\begin{tabular}{|c|c|c|c|}
\hline 1.By University & No. & Percent & $\chi^{2}$ value \\
\hline TU & 10 & 17.9 & \\
PU & 4 & 5.3 & \\
KU & 15 & 30.0 & $\mathrm{P}=0.001$ \\
PoU & 1 & 4.3 & \\
\hline BPKIHS & 11 & 61.3 & \\
\hline Total row \% & 41 & 18.5 & \\
\hline 2. By gender & & & \\
\hline Male & 31 & 31.0 & \\
\hline Female & 10 & 8.2 & $\mathrm{P}=<0.001$ \\
\hline Total & 41 & 18.5 & \\
\hline 3. By designation & & & \\
Instructor/Asst. & 9 & 14.5 & \\
Lecturer & & 11.5 & $\mathrm{P}=<0.001$ \\
\hline Lecturer & 12 & 38.5 & \\
\hline Reader/Professor & 20 & $\mathbf{1 8 . 5}$ & \\
\hline Total & 41 & & \\
\hline
\end{tabular}

Table 4 shows that only $18.5 \%$ of HE teachers (18.5\%) have published a paper based on a systematic review. The proportion was highest amongst HE teachers from BPKIHS. As expected, more men than women had published a systematic review paper $(P<0.001)$. By designation, a little more than one-third of the Readers/Professors reported that they have published a systematic review paper.

One-third of the total HE teachers (35\%) have participated in international workshop and seminars. The proportion is highest from BPKIHS (74\%) followed by KU (43\%) and TU (395). The proportion seems lower in PU (14\%) and PoU $(26 \%) \quad(P=<0.001)$. By sex, female participation in international research seminars tends to be very low (21\%) compared to the males (52\%) $(\mathrm{P}=<0.001)$. Key informants, particularly the principals from nursing colleges from all HEls alike, reiterated that female teachers from nursing backgrounds were not getting fair opportunity for any research training conducted by either the university or by the outside organisations. 
"We have 50 to 60 nursing teachers working in our college. Hardly one or two teachers may get opportunity to participate in a research-related training in one year. Others have to wait until they retire" -Key Informant, Institute of Medicine, TU

Another key informant from BPKIHS also suggested:

"The faculty of nursing should be included in any training/workshops related to research, curriculum review and other activities organized by the institute and/or other external organizations as this has been overlooked since long time" -Key Informant, BPKIHS

More than two-third of the Readers/Professors (68\%) reported they had participated in international training and conferences, far more than the percentage reported by assistant lecturers/instructors and lecturers (28\%) $(P=<0.001)$.

\section{Training Needs}

Most of the interviewees said teachers were not competent in teaching research literature access and needed more exposure and appropriate training. Few said there was a need to subscribe to electronic databases.

"To be frank, there is not really a competent teacher on teaching electronic research except the teachers who are young, energetic and active in research. For student, our software supporter help them, things have been running like this. The main reasons are that necessity of database has not realized yet." -Key Informant, TU

All the participants recognized the need for training e.g.:

"No any trainings and classes for teachers regarding computer is given, if you want to learn it you should go to institutions paying yourself or you can learn from your friends as well." -Key Informant PoU

More worryingly, some did not use electronic databases at all:

"We generally use library and books. Not really use online data base." -Key informant, $P U$

"No special training has yet been conducted ... (we) provided HINARI user name and password to students. That's all. The teachers share ideas with each other."

-Key informant, Institute of Medicine, TU

Some highlighted that often only those staff trained abroad had the appropriate internet-based skills to teach:

"We are not able to conduct any training. ... Only very few teachers... Ph.D. from abroad are used to this matter. But those who have studied in Nepal feel lagging behind in surfing online literature." -Key informant PoU

Most of the HEls suggested training young faculty so that they could deliver best teaching on accessing research literature. One example is given below.

"There is a need to upgrade the knowledge and ability of young faculty members in teaching/delivering research methodology as a whole, and in particular on accessing research literature. It will be helpful to further enhance the research capacity of the institute". -Key Informant BPKIHS Others had specific solutions in mind for both staff and students, for example:
"I think we need to develop a modular training for teachers and students on how to access research literature." - Key Informant, BPKIHS

\section{Perceived Need for Revision of Curricula}

The general agreement was that a revision of the curriculum was due. The system of curriculum revision, however, differed between universities. Few were in favour of revising at least every four year.

"We are flexible concerning this matter and the focus should be given to $\mathrm{BPH}$." -Key Informant PoU

It also became clear that the process of changing the curriculum often was very bureaucratic, e.g.:

"It depends on department but basically the department discus first, then the case goes to Subject Committee, after that, Faculty handles and makes a decision. In my opinion, the curriculum should be flexible in order to incorporate new topics since these are lacking and needs to be updated."

- Key Informant, KU

One key informant expressed lack of timely revision of the HE curricula thus:

"Seventh batch of BHP students have passed out but no curriculum has been revised yet. We are positive to incorporate these issues in our course; it must be addressed in the course. We have been teaching the same course for seven years". -Key Informant, Institute of Medicine, TU

A room to revising HE curricula clearly appeared in one statement:

"Definitely, we can incorporate such new issues in our curricula. Recently we have submitted a proposal to revise master's course in Nursing. Though we have been running 10 classes about online literature review by librarian but still if the student feels lack we can address this issue in our course." -Key informant, IOM,TU

Key informants from BPKIHS opined to review the curricula as well as teaching methods in order to incorporate and deliver research components effectively.

"There is a growing need of periodic review of curricula/teaching methodology with external support from WHO, senior faculty members from TU and others. " -Key informant, BPKIHS.

\section{Discussion}

\section{DELPHE Project}

In collaboration the Universities of Sheffield and Bournemouth and Tribhuvan University and a number of medical colleges in Nepal, with financial support from the British Council/DFID, we successfully completed a DelPHE (Development Partnerships in Higher Education) project. The project aimed to build the capacity of higher education institutions to access and utilise research-based information in the medical, nursing and public health fields. The use of available evidence-based information in higher education is a must for addressing health-related problems in the country. Currently, there is a lack of knowledge, as well as resources for utilising research findings that are in open access and/or low cost journals. The project was a milestone in achieving the health-related MDGs (Millennium Development Goals) in Nepal through the 
development of health and medical research capacity and creation of enabling environment ${ }^{11}$.

\section{Utilisation of research-based information among the HE} Teachers

The global information and communication revolution is not only challenging teaching and learning, but also the way that academe conventionally reaches its audience and gains academic reputation. Both public and private funders of research pressure higher education institutions to make research findings more readily and quickly available, for example, through free-access on the Internet ${ }^{12}$. There is substantial increase in on-line academic journals and a movement in some countries to place the onus and cost of an individual's publication with her/his academic home institution. Also, the number of academics who publish their own work on the Internet is growing ${ }^{13-14}$. Since universities are traditionally engaged in both education and research (and, more recently, the validation of research), they are in a good position to help make research-based knowledge benefit society at large. Collaboration between active researchers and students is one of the best channels for new scholarly knowledge to be spread, contested and advanced in the professional community. Furthermore, learning from the most up-to-date scholarly knowledge and experience is a key ingredient in good teaching. Paradoxically, researchers are expected to introduce the most complex research findings to students who have much less disciplinary knowledge, but in many settings teachers are not offered adequate support to develop such pedagogic competence ${ }^{14-15}$.

Although there are programmes intended to enhance faculty development in health-care professions, few of these have been adequately evaluated concerning their impact on science and clinical science faculty members including clinician-teachers ${ }^{16}$. The lack of published information regarding faculty development strongly suggests a lack of evidence-based programmes. Substantial steps are now required toward the development of faculty development programmes. Furthermore, evaluations must encompass all faculty subgroups, including tenure and nontenured track, women, and underrepresented minorities ${ }^{17-}$ 19

In our study just over one in four HE teaching staff (41.7\%) had published in an academic peer reviewed journal, and men were considerably more likely to have published (60.9\%) than women (30.6\%), and higher ranking staff such as Readers and Professors were considerably more likely to publish (71.4\%) than Instructors and Assistant Lecturers (28.1\%). Just $13.8 \%$ had published in international peer reviewed journals and only marginally more had published in national peer-reviewed journals, although more had participated in international research conferences or workshops (28.0\%). There was a clear gender difference in the latter, with $42.2 \%$ of men taking part in international conferences or workshops but only $19.8 \%$ of women. It supports the studies done in other part of the world ${ }^{19-22}$

Across the five universities, some $85 \%$ claimed to have basic computer skills. Almost all HE teachers at BPKIHS (96\%) claimed this. However, key informant interviews reported that significant minority of teachers from across all universities lack computer skills. Only $14 \%$ HE teachers selfreported they had 'advance' computer skills. KU teachers were most likely to have advanced computer skills (21\%) followed by PU (16\%). In the other three universities, this proportion was less than one in ten. More than nine in ten (93\%) had a computer at home. Female staff were considerably less likely to have work email than men $159 \%$ versus $76 \%$ ) were, and all men and $87.5 \%$ women had a personal email account. Key informant interviews revealed that young faculties are more likely to have access to computer and personal email address.

The key informants considered that majority of teachers were not confident enough on accessing online research literature, as they were not taught this at the postgraduate level. Nor they had opportunity to take part in any shortterm training on accessing research literature during their professional career. The study participants suggested focusing on full time, female, young, and motivated $\mathrm{HE}$ teachers for any future training on accessing research literature. Almost all HE teachers (94\%) were keen to participate in a learning workshop on accessing research literature. The majority was willing to come for four or more days training.

A number of factors that could enable or hinder accessing of research literature by the HE teachers and students were explored. Availability of physical facilities was considered one main prerequisite for this. The study revealed that computers and internet were available at nearly all $\mathrm{HE}$ institutions (98.8\%), and all had a library. Nine out of ten (89.3\%) teachers had computer access for academic purpose. The proportion of male staff (92.6\%) was a litter higher than for females (86.8\%) and instructors and assistant lecturers had lower access (83\%) to computers for academic use, a finding which was slightly low compared to the study by Bediang et al. in Cameroon ${ }^{22}$.

Nearly one fifth of the HE teachers (19.3\%) were even unaware whether they could get support from a librarian at their HEI. Others (11.9\%) reported that a librarian was not physically present to providing support needed by them. Two out of 12 principals were even not aware about the kind of support that their librarians could provide to the students and teachers. Cooper and Crum explored the new activities and changing roles of health sciences librarians in their systematic review ${ }^{23}$.

Whether or not electronic research databases were available and used by the HE teachers was the another key question of the study. On the whole, 119 out of 244 (48.8\%) HE teachers reported that they had access to electronic research databases at their HEls. The study suggests that having access to electronic databases varied widely between institutions and disciplines. HINARI, an online research database made freely accessible by WHO, was the most used electronic databases mentioned (43\%), it was followed by PubMed (16\%). There was confusion amongst the HE teachers that statistical packages such as SPSS and Epi-Info belong to the research databases. Key informant interviews informed that students and faculties mostly use HINARI and PubMed. Many of them used Google 
for relevant materials but suspected on their authenticity. Our study finding was contradictory to the study by Maggio et al. which proved PubMed as the most commonly used database ${ }^{24}$. Almost all key informants and HE teachers, except from BPKIHS, reported their institutions had not subscribed to online journal that involved a subscription fee, i.e. had a cost.

As external funding support is very important to strengthen research capacity of HEls, particularly in a resource poor setting, we had asked the HE teachers whether their institutions had received any funding support from the external development partners. In total only $22.9 \%$ respondents reported that their institutions had received funding to strengthen research capacity of teachers and students. Moreover, the key informants reiterated that there was a lack of institutional linkage among the key stakeholders involved in health research in Nepal such as NHRC, universities and medical colleges, external development partners and WHO, among others.

Our findings suggest that research in general and accessing of research literature in particular was included with different approaches and the scope of contents was also variable. Less than half of the teachers (48.8\%) were involved in teaching a course on health or medical research. Out of those 199 teachers, 98(82.4\%) self-reported they teach accessing research literature. When this number was matched with the total number of teachers $(\mathrm{N}=244)$, only $40 \%$ teachers appeared to be involved in teaching accessing research literature to the students.

Most HE teachers (84\%) have taught research courses for less than five years. Those who teach research methods were more likely to include manual search (61.2\%) and online search other than electronic database (63.3\%). But only $41.8 \% \mathrm{HE}$ teachers teach access to the online research literature, ranging from $20.8 \%$ to $57.1 \%$ across institutions. By discipline, it varies from $38.7 \%$ in nursing to $50 \%$ each in pharmacy and dentistry. Those who taught research methods were more likely to give their students assignments based on accessing the research literature $(63 \%)$ against the total teachers (30.7\%). Less than half of the $\mathrm{HE}$ teachers were taught about accessing electronic research databases (43.9\%), 'it was not in the curriculum' was the main reason for not teaching it (88.3\%). Key informants informed that many students copy thesis from their seniors and no software is being used to measure plagiarism. Furthermore, the issue of plagiarism is not included in the HE courses and teachers not been sensitised. This is one area the DelPHE project should focus while at designing a teacher training manual in the future. The study recommends to Improve facilities such as computers, broadband internet access, back-up power supply, furniture and space for computer labs for teaching faculty, librarians and students; subscribe to online journals; Secure more funding for research in HEls, Establish institutional links with national research institutions such as NHRC, and universities, and international research organizations/universities; and provide research methods training to staff (librarians and HE teachers). Moreover, females, young and motivated faculties, specifically working on full time should be selected for any training on accessing research literature.

\section{Future Scope of the Study}

It is promising for DelPHE partners to discuss and decide on the modality of the training; whether to provide a Master Training of Trainers (MTOT) to selected teachers or basic training to as many teachers as possible. Possibility of developing and implementing modular training to faculty/students on accessing research literature could also be considered.

Perhaps start by organising training on systematic reviews. To create research-friendly environment and develop a research culture, there should be provision of research fellowships and small grants to encourage and motivate young faculty members who are early career research professionals in the faculty.

\section{Conclusion}

The study indicates that there is a growing need for the periodic review of health and medical sciences curricula and teaching methodologies. The findings of this study should be used to advocate and sensitise curriculum development centres and university authorities for the review and revision of the curricula and include accessing of research literature with considerable importance. Finally, the authors would like to note that intra-university variations in findings in terms of curricula, research infrastructure, teaching methods and publications should not be taken as an evaluation findings, hence they are presented here as a snap-shot during the point of time study was undertaken.

\section{Author contributions}

EvT, PS, BD designed the study, BD and RSP collected data, PS and EvT drafted the manuscript. BS critically revised the manuscript and helped in data analysis and interpretation. All authors commented on various drafts of the manuscript. All the authors approved the final document.

\section{Acknowledgments}

We like to thank the local coordinators:

Mrs. Janet Ashwell, Lalipur Nursing College, Kathmandu; Prof Paras K. Pokharel at School of Public Health \& Community Medicine, BP Koirala Institute of Health Sciences;

Dr Shyam Lohni, Nobel College, Pokhara University, Kathmandu

Dr Suraj Maratha, MMIHS, Kathmandu Nepal

Dr Dayaram Lamsal Chitwan Medical College, Chitwan

Dr Shishir Gokhale, Manipal College of Medical Sciences, Pokhara

We like to express our appreciation to all participants who completed the questionnaire and took part in in-depth interviews and last not least, the British Council and DELPHE for funding this work.

\section{Conflict of interest:}

There is no conflict of interest among authors arising from the study. 


\section{References:}

1. Dixit H. Book Review of Chikitsa Shikshama Fadko, by Prof. Dr. Sitaram Adhikari, Published by: SHIKSHAK Masik in Asar 2070 (June 2013), Pages: 390, Price: Rs. 400/-, Journal of Kathmandu Medical College 2013, 2(2): 97-103.

2. Arunachalam S. Information for research in developing countries - information technology, a friend or foe, International Information \& Library Review 2003, 35(2-4): 133-147.

http://dx.doi.org/10.1016/S1057-2317(03)00032-8

3. Simkhada P, Baral YR, van Teijlingen ER. Bibliometric review of research publications in Nepal. Asia-Pacific Journal of Public Health 2010, 22(4): 492-500 web address http://aph.sagepub.com/content/22/4/492.full.pdf+html

4. Acharya GP. Health research in medical colleges, Kathmandu University Medical Journal 2003, 2(6): 85-88

5. Simkhada P, van Teijlingen E, Pokharel T, Devkota B, Pathak RS. Research Methods Coverage in Medical \& Health Science Curricula in Nepal, Nepal Journal Epidemiology 2013, 3(3): 253-258. www.nepjol.info/index.php/NJE/article/view/9185

6. Aronson B. Improving online access to medical information for low-income countries, New England Journal of Medicine 2003, 350(10): 966-968. http://dx.doi.org/10.1056/NEJMp048009

PMid:14999107

7. Sadana R, D'Souza C, Hyder AA, Mushtaque A, Chowdhury R. Importance of health research in South Asia, Brit Med J 2004, 328(7443): 826-830. http://dx.doi.org/10.1136/bmj.328.7443.826

PMid:15070643 PMCid:PMC383385

8. van Teijlingen E, Hundley V. Pilot studies in family planning \& reproductive health care, Journal of Family Planning \& Reproductive Health Care 2005; 31(3): 219-21. http://dx.doi.org/10.1783/1471189054483735

PMid:16105287

9. Sathian B, Sreedharan J, Baboo NS, Sharan K, Abhilash ES, Rajesh E. Relevance of Sample Size Determination in Medical Research. Nepal Journal of Epidemiology 2010; 1(1):

4-10.

http://dx.doi.org/10.3126/nje.v1i1.4100

10. Forrest Keenan K, Teijlingen van ER, Pitchforth E. The analysis of qualitative research data in family planning and reproductive health care, Journal of Family Planning \& Reproductive Health Care 2005, 31(1): 40-43. http://dx.doi.org/10.1783/0000000052972825

PMid:15720849

11. Simkhada P. Public Health: DELPHE Project, Partnership on Improving Access to Research Literature for Higher Education Institutions in Nepal (PARI Initiative). Available from: http://www.sheffield.ac.uk/scharr/sections/ph/research/i nthealth/delphe

12. Perkman $M$, Tartari V, McKelvey $M$, Autio E, Broström A, D'Este P. et al. Academic engagement and commercialisation: A review of the literature on university-industry relations, Research Policy 2013, 42: 423-442.

http://dx.doi.org/10.1016/j.respol.2012.09.007

13. Batty D. Journals 'regularly publish fraudulent research'. [online] 1996. Available from: http://www.guardian.co.uk/society/2006/may/03/health. medicineandhealth

14. Sathian B. Methodological Rigors in Medical Journals from Developing Countries: An Appraisal of the Scenario in Asia. Nepal Journal of Epidemiology 2011, 1(5): 141143.

http://dx.doi.org/10.3126/nje.v1i5.6151

15. Guglielmo BJ, Edwards DJ, Franks AS, Naughton CA, Schonder KS, Stamm PL, et al. A critical appraisal of and recommendations for faculty development. American Journal of Pharmaceutical Education 2011, 75(6): Article 122.

http://dx.doi.org/10.5688/ajpe756122

PMid:21931460 PMCid:PMC3175674

16. Lancaster JW, Stein SM, Garrelts MacLean L, Van Amburgh J, Adam M, Persky AM. Faculty Development Program Models to Advance Teaching and Learning Within Health Science Programs. American Journal of Pharmaceutical Education 2014, 78(5): article 99. http://dx.doi.org/10.5688/ajpe78599

17. Davis G, Foley BJ, Horn E, Neal E, Redman R, Van Riper M. Creating a comprehensive faculty development program. Journal of Faculty Development 2003, 19(1): 1928.

18. Duch J, Zeng XHT, Sales-Pardo M, Radicchi F, Otis S, Woodruff TK, Nunes Amaral LA. The Possible Role of Resource Requirements and Academic Career-Choice Risk on Gender Differences in Publication Rate and Impact. PLoS One. 2012, 7(12): e51332. http://dx.doi.org/10.1371/journal.pone.0051332 PMid:23251502 PMCid:PMC3520933

19. Xie Y, Shauman KA. Sex differences in research productivity: New evidence about an old puzzle. American Sociological Review 1998, 63: 847 http://dx.doi.org/10.2307/2657505

20. Prpić K. Gender and productivity differentials in science. Scientometrics 2002, 55: 27-58 http://dx.doi.org/10.1023/A:1016046819457

21. Larivière $V$, Vignola-Gagné $E$, Villeneuve $C$, Gélinas $P$, Gingras Y. Sex differences in research funding, productivity and impact: An analysis of Qúebec university professors. Scientometrics 2011, 87: 483-498. http://dx.doi.org/10.1007/s11192-011-0369-y

22. Bediang G, Stoll B, Geissbuhler A, Klohn AM, Stuckelberger A, Nko'o S, Chastonay P. Computer literacy and E-learning perception in Cameroon: the case of Yaounde Faculty of Medicine and Biomedical Sciences. BMC Medical Education 2013, 13: 57. http://dx.doi.org/10.1186/1472-6920-13-57 
PMid:23601853 PMCid:PMC3637556

23. Cooper ID, Crum JA. New activities and changing roles of health sciences librarians: a systematic review, 19902012. Journal of the Medical Library Association 2013, 101(4):

268-277.

http://dx.doi.org/10.3163/1536-5050.101.4.008

PMid:24163598 PMCid:PMC3794682

24. Maggio LA, Tannery NH, Chen HC, ten Cate O, O'Brien B. Evidence-based medicine training in undergraduate medical education: a review and critique of the literature published 2006-2011. Academic Medicine 2013, 88(7): 1022-1028.

http://dx.doi.org/10.1097/ACM.0b013e3182951959

PMid:23702528

\section{Article Information}

\section{Article history}

\begin{tabular}{|l|c|}
\hline Received & $15^{\text {dth }}$ August 2014 \\
\hline Received in revised form & $19^{\text {th }}$ September 2014 \\
\hline Accepted & $22^{\text {rd }}$ September 2014 \\
\hline
\end{tabular}

